Otol Neurotol. 2011 September ; 32(7): 1185-1188. doi:10.1097/MAO.0b013e31822a28df.

\title{
The Ossicle of Paaw
}

Evan M. Graboyes, AB, Richard A. Chole, MD, PhD, and Timothy E. Hullar, MD

Department of Otolaryngology, Washington University in St. Louis, St. Louis, Missouri, USA

\begin{abstract}
Some anatomists have reported more than three ossicles within the middle ear. The most widely discussed of these is the lenticular ossicle, which we now understand to be the lenticular process forming the distal tip of the long process of the incus. Another supernumerary ossicle, within the stapes tendon, has also been described by a number of anatomists. Here, we examine the history of this ossicle's discovery, sources of confusion concerning its existence in humans, and its presence in some mammalian species. We also discuss the variability in the nomenclature of supernumerary ossicles for historical accounts.
\end{abstract}

\section{Keywords}

ossicle; Paaw; fourth ossicle; stapes; tendon; sesamoid; ossiculum quartum; osseus globulus; ossiculum ovale

Beginning in the 1600s, anatomists began to report that they had identified other ossicles in addition to the malleus, incus, and stapes. The most widely discussed of these additional ossicles was the "lenticular ossicle" $(1,2)$. Although now recognized to represent the lenticular process forming the distal tip of the incus, its existence as a separate bone was a subject of controversy from the early $17^{\text {th }}$ century until the late $18^{\text {th }}$ and early $19^{\text {th }}$ century (3-9). In fact, the existence of this ossicle has continued to be debated into the latter portion of the $20^{\text {th }}$ century $(1,10,11)$.

After the "lenticular ossicle," the most widely discussed additional ossicle is a sesamoid bone thought to be located within the stapedial tendon. This ossicle was described in both humans and non-human mammals $(8,12-19)$. It is of particular interest because it may actually exist, at least in some mammalian species (20-24). Unfortunately, both it (13-19) and the "lenticular ossicle" $(1,3,6-8,25-29)$ have been referred to as the "fourth ossicle," confusing its description in historical accounts $(1,19,30)$.

In 1615, Pieter Paaw, an anatomist and botanist at Leiden, was likely the first to describe a sesame-shaped ossicle within the stapes tendon of oxen ("Observavi in capite bubulo frequenter hisce tribus ossiculis se iungere quartum sesamo simile, sed non nisi in annos id vidi") (12). Soon after his initial description, other anatomists began to write about this sesamoid bone in both humans and non-human mammals. Johannes Vesling, Professor of Anatomy in Padua, called it the "fourth ossicle" ("ossiculum quartum") and the "small bone" ("ossiculum parvum") (13). He wrote that it was round, very small, and joined with the stapes ligament, but did not specify in which species he found the bone (Figure 1). Like many other anatomists, Vesling gave credit for the ossicle's discovery to Franciscus Sylvius, despite the latter having being born only one year after Paaw's work was published

Corresponding Author: Timothy E. Hullar, MD, Campus Box 8115, St. Louis, MO 63110 USA, 314-362-7509, 314-362-7522, FAX HullarT@wustl.edu. 
("Stapedis aditur ossiculum quartum, rotundum, perexiguum, ligamento Stapedis innexum, quod Francisco Sylvio inventum adscribitur")(13). Many other anatomists have also made this attribution to Sylvius $(13-16,19,30)$. [Note that later interpretations have concluded that Vesling's term "ligamento Stapedis" actually indicated the stapedial tendon, which is consistent with his illustration $(19,30)$.]

In 1642, Nicolas Fontano wrote of a fourth ossicle in the stapes tendon of both humans and cattle (14). He described it as round in shape, resembling the scale of a wolf-fish ("Ejus forma rotunda est, squammae lupi piscis similis") and noted it was easier to find in humans after studying the larger version in cattle. Thomas Bartholin, a $17^{\text {th }}$ century Danish anatomist, also reported a "fourth ossicle" ("os quartum subrotundum") in the stapes tendon $(15,16)$. He described it as round and slender and attached to the side of the stapes $(16)$. Bartholin illustrated the ossicle in both humans and calves (15) (Figure 2). Like Fontano, he indicated that the ossicle was more evident in the heads of calves because the bone was bigger in them than in humans.

Caecilius Folius, a contemporary of Bartholin's and successor to Vesling in Padua, indicated the globular morphology of the ossicle by calling it the "osseus globulus" in 1645 (17) (Figure 3). Folius credited Bartholin for its description ("Stapedis osseus quidam globulus à Th. Bartholino in Anatomia Parentis descriptus"), although Bartholin had credited Sylvius for the same discovery $(15,17)$.

Hermann Friedrich Teichmeyer published an entire thesis of twenty-seven pages devoted solely to the auditory ossicles in 1727 (19). In this text, he discussed and depicted an "oval ossicle" within the stapes tendon in humans ("quod ossiculum quartum, ovale a me vocatum"). In a chapter dedicated to this ossicle, he summarized the descriptions of it in both humans and animals during the previous one hundred years. Teichmeyer reproduced figures from Vesling and Bartholin to illustrate the ossicle in the stapes tendon as well as providing his own representation of it (Figure 4).

Soon after its description, several anatomists began to doubt the existence of an ossicle within the stapes tendon. Johannes Riolanus addressed the question in depth in a chapter in his 1649 commentary on Bartholin's Anatomia Reformata entitled "Is there a fourth bone in the ear?" He concluded that the ossicle did not exist in either humans or cattle (31). In 1652, Domenico de Marchetti reported that he was unable to find the same structure that Sylvius and Vesling had described (32). Gerhard Blasius, in his 1666 commentary on Vesling's text, seconded De Marchetti's skepticism (33).

Some authors felt the ossicle was present in some, but not all, species. In 1684, Günther Christoph Schelhammer wrote that it might exist in pigs but not in humans ("In ejus tendine nonnunquam ossiculum reperitur, "ut ego reperi in sue, \& etiam aliis") (18). Both Paaw, in 1615, and Joseph Hyrtl, in his 1845 monograph on the comparative anatomy of the middle and inner ears of mammals, described the bone in cattle. Hyrtl also described it in horses and tapirs (8) (Figure 5). Neither Paaw nor Hyrtl specifically mentioned the bone in humans $(8,12)$.

Modern studies have confirmed that some mammals do in fact have a structure in the stapedial tendon as originally described by Paaw $(12,20-24)$. It has been described in the white-nosed coati Nasua narica, the pale kangaroo mouse Microdipodops pallidus, and Seba's short-tailed bat Carollia perspicillata (20) (Figure 6). It has been extensively described in a number of other species of bats, including Pallas's long-tongued bat Glossophaga soricina, the greater horseshoe bat Rhinolophus ferrumequinum, and Mexican greater funnel-eared bat Natalus mexicanus (21). It has also been found in the Virginia opossum Didelphys virginiana Kerr (22), the short-tailed opossum Monodelphis 
brevicaudata (23), and the nine-banded armadillo Dasypus novemcinctus (24). The bone has been theorized to decrease friction between the stapes tendon and the adjacent mucus membranes lining the tympanic cavity of the middle ear (21). To the authors' knowledge there is no current evidence for an ossicle of Paaw in humans.

A careful review of the literature indicates that some authors have misinterpreted prior work on the sesamoid bone in the stapes tendon. For example, the "lenticular ossicle" purportedly located between the incus and stapes has also been called the "fourth ossicle" at various points in history $(1,3,6-8,25-29)$. Several historical descriptions of supernumerary ossicles have confused the "ossicle" located at the end of the long process of the incus with the "ossicle" located within the stapedial tendon $(1,19,30)$. For example, according to Politzer, Vesling's description of the lenticular process, or fourth ossicle, was inaccurate because Vesling located it within the stapes tendon ("weniger das Linsenbein, von ihm 'Ossiculum quartum' genannt. Dieses beschreibt er als dem Steigbügelligament (wofür er die Sehne des Musc. Stapedius hält) eingefügt") (30). Vesling, however, did not actually appear to be describing or illustrating the lenticular ossicle but rather the ossicle within the stapes tendon (13). Regarding Folius, Politzer claimed that his "osseus globulus" corresponds to the lenticular process ("Was Folius als Stapedis osseus globulus in diese Abbildung bezeichnet, wird von Manchen als das Linsenbein gedeutet" (30). Politzer provides no citations to support this claim, and the ossicle described by Folius is pictured as an anatomic structure located within the stapes tendon (17). In his discussion of the ossicles in 1763, Albrecht Von Haller claimed that de Marchetti denied the existence of the fourth ossicle located between the incus and the stapes (34), when de Marchetti in fact denied the existence of the ossicle within the stapes tendon (32). Teichmeyer cited the English anatomist James Drake as recognizing an "os ovale" in the tendon of the stapedial muscle (19), but actually Drake wrote that the fourth ossicle is the "Os Orbiculare," a "round thin Bone; Concave on one side, and Convex on the other. On the Concave side it receives the Head of the Stapes, and the Convex is receiv'd by the Process of the Incus" (35). It seems relatively clear that Drake was describing the lenticular ossicle thought to exist between the incus and the stapes, not an ossicle within the stapes tendon.

\section{Conclusions}

A sesamoid bone exists within the stapes tendon in certain mammalian species, although it does not exist in humans. Descriptions of this additional ossicle in the stapes tendon have been misinterpreted by authors, confusing its terminology and history.

\section{Acknowledgments}

Supported by NIH P30 DC04165-11 (RAC) and NIH K08 DC006869 (TEH). Grateful thanks to Mark Peterson for assistance with historical references and Drs. Avery Springer and Michael Claiborne for Latin translations.

\section{References}

1. Asherson N. The fourth auditory ossicle: fact or fantasy? J Laryngol Otol. 1978; 92:453-65. [PubMed: 351110]

2. Graboyes E, Hullar T, Chole R. The lenticular process of the incus. Otol Neurotol. accepted for publication.

3. Perrault, C. Essais de Physique. Paris: Jean Baptiste Coignard; 1680.

4. Blumenbach, JF. Geschichte und Beschreibung der Knochen des menschlichen Körpers. Göttingen: Jean Christian Dieterich; 1786.

5. Soemmerring, ST. Abbildungen des Menschlichen Hoerorganes. Frankfurt: Varrentrapp and Wenner; 1806. 
6. Shrapnell HJ. On the Structure of the Os Incus. London Medical Gazette. 1832; 12:171-4.

7. Hagenbach, E. Die Paukenhöhle der Säugethiere. Leipzig: Weidmannsche Buchhandlung; 1835.

8. Hyrtl J. Vergleichend-anatomische Untersuchungen über das innere Gehörorgan des Menschen und der Säugethiere. Prague: Friedrich Ehrlich. 1845:82-84.

9. Eysell A. Beiträge zur Anatomie des Steigbügels und seiner Verbindungen. Archiv für Ohrenheilkunde. 1870; 5:237-49.

10. Pal'chun VT, Magomedov MM. Some anatomical features of the long process of the incus [In Russian]. Vestn Otorinolaringol. 1997:19-20. [PubMed: 9163123]

11. Gaudin EP. Biophysical considerations of some problems in tympanoplasties. J Laryngol Otol. 1969; 83:1135-42. [PubMed: 5360029]

12. Paaw, P. Primitiae anatomicae. De Humani Corporis Ossibus. Leiden: à Colster; 1615. p. 55

13. Vesling, J. Syntagma Anatomicum. Padua: Pauli Frombotti; 1651. p. 251-252.

14. Vesalius, A. De Humani Corporis Fabrica Epitome: cum Annotationibus Nicolai Fontani. Amsterdam: Joannes Janssonius; 1642. p. 4

15. Bartholin, T. Institutiones Anatomicae. Leiden: Franciscus Hackius; 1645. p. 408-411.

16. Bartholin, T. Anatomia Reformata. Leiden: Franciscus Hackius; 1651. p. 490-493.

17. Folius, C. Nova Auris Internae Delineatio. Venice: Joannes Antonius Julianus; 1645.

18. Schelhammer, GC. De Auditu Liber Unus. Leiden: Peter de Graaf; 1684. p. 44-46.

19. Teichmeyer, HF. Dissertatio Medica Solennis Sistens Vindicias Quorundam Inventorum Meorum Anatomicorum A Nonnullis Celebratissimis Anatomicis In Dubium Vocatorum. Jena: Müller; 1727. p. $15-29$.

20. Hinchcliffe R, Pye A. Variations in the middle ear of Mammalia. J Zool. 1969; 157:277-88.

21. Henson ODW Jr. Some morphological and functional aspects of certain structures of the middle ear in bats and insectivores. Univ Kans Sci Bull. 1961; 42:151-255.

22. McCrady E Jr. The embryology of the opossum. Am Anat Mem. 1938:16.

23. Wible J. On the cranial osteology of the short-tailed opossum monodelphis brevicaudata (didephidae, marsupialia). Ann Carnegie Mus. 2003; 72:137-202.

24. Wible J. Petrosal anatomy of the nine-banded armadillo, Dasypus novemcinctus Linnaeus, 1758 (Mammalia, Xenarthra, Dasypodidae). Ann Carnegie Mus. 2010; 79:1-28.

25. Mery, J. Description exacte de l'oreille de l'homme. Paris: Lambert Roulland; 1681.

26. Lamy, G. Explication mechanique et physique des fonctions de l'ame sensitive. Paris: Lambert Rolland; 1681.

27. Du Verney, J-G. Traité de l'organe de l'ouïe. Paris: Estienne Michallet; 1683.

28. Cassebohm, JF. Anatomici de Aure Humana. Halle: Orphanatrophei; 1734.

29. Blumenbach, JF. A short system of comparative anatomy. London: Longman, Hurst, Rees, and Orme; 1807.

30. Politzer, A. Geschichte der Ohrenheilkunde. Stuttgart: Enke; 1907.

31. Riolanus, J. Opuscula Anatomica Noca. London: Milonis Flesher; 1649. p. 427

32. de Marchetti, D. Anatomia. Padua: Matthaeus Bolzetta; 1652. p. 138-139.

33. Vesling, J. Syntagma Anatomicum: Commentario atque appendice. Amsterdam: Joannes Janssonius à Waesberge, \& Elizeum Weyerstraet; 1666. p. 251-252.

34. von Haller, A. Elementa physiologiae corporis humani. Lausannae: Francois Grasset; 1763. p. 214-215.

35. Drake, J. Anthropologia Nova: or, a new system of anatomy. London: Innys; 1717. p. 334-341. 


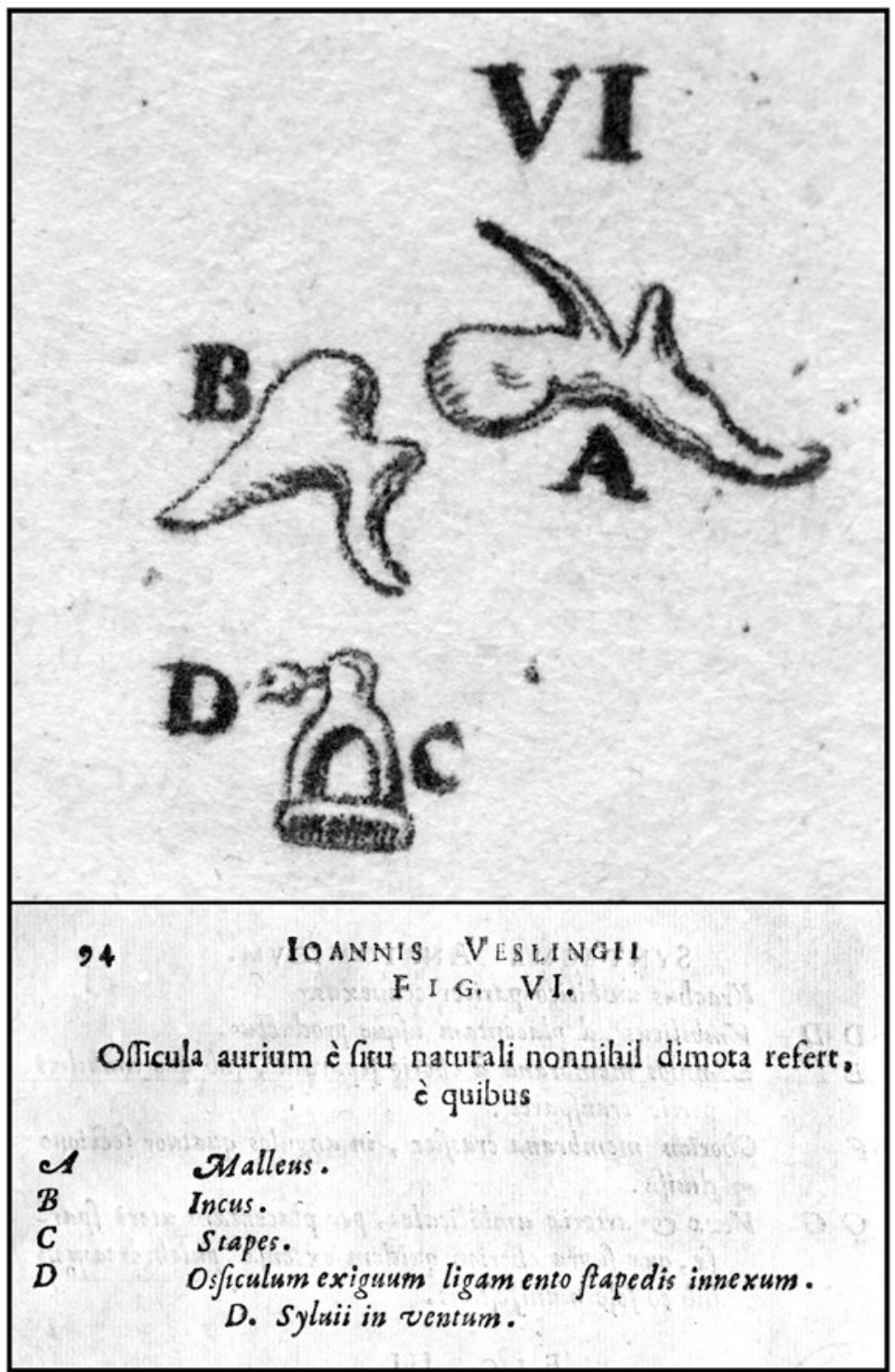

Figure 1.

A depiction of the auditory ossicles by Johannes Vesling in his 1651 edition of Syntagma Anatomicum. He used the term "ossiculum parvum," or small ossicle, to indicate a structure attached to the side of the stapes capitulum (D). 


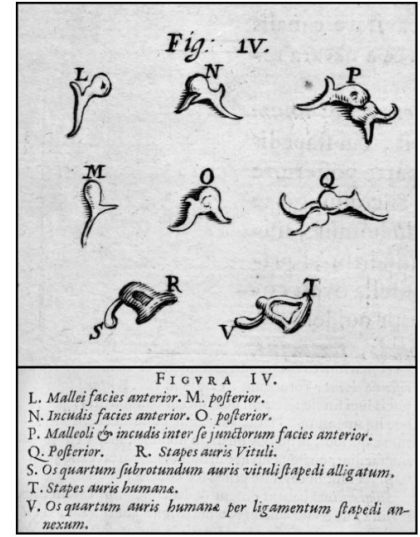

Figure 2.

A representation of the auditory ossicles from Thomas Bartholin's 1645 text Institutiones Anatomicae. Bartholin labeled his depiction of the additional ossicle in a calf (S) and human (V) as the "os quartum subrotundum" and showed it connected to the stapes in a calf (R) and human $(\mathrm{T})$. 


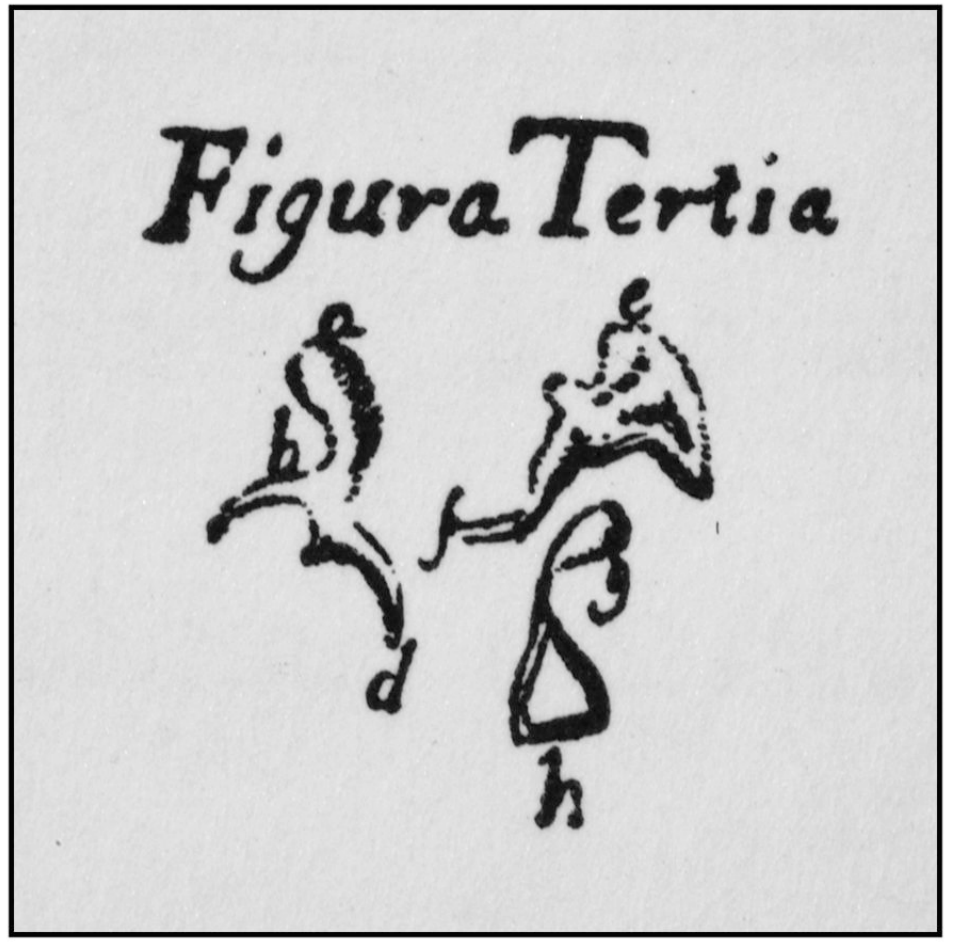

Figure 3.

An illustration of the ossicles from Caecilius Folius' 1645 edition of Nova Auris Internae Delineatio demonstrating an additional ossicle that Folius called the "osseus globulus" (g), shown within the adjacent stapes tendon. Folius did not specify if his illustration was based on human tissue. A similar figure can be found in Thomas Bartholin's 1651 edition of Anatomia Reformata. 


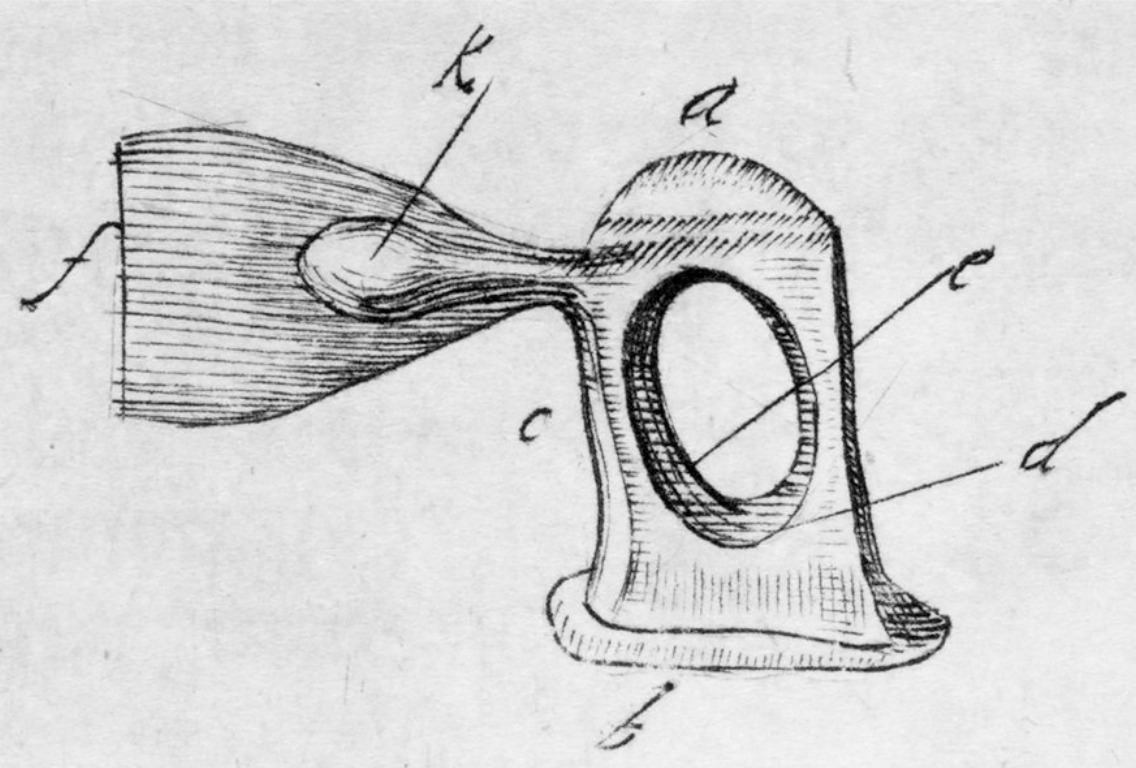

Stapes, per microfcopium confideratus. a. Officulum femilunare in capite ftapedis. b. Bafis ftapedis.

c. Crura ftapedis excavata. d. e. Foramina, qua tympanis, fecundo \& tertio, claudustwe. f. Mufculus CASSERII. k. Olficulum quartum ovale.

Figure 4.

An illustration of the stapes, reproduced from Teichmeyer's 1727 thesis Dissertatio Medica, in which he defends the existence of a "fourth," or "oval ossicle" (k) located within the tendon of the stapedial muscle in humans (f). Image courtesy of the Division of Rare and Manuscript Collections, Cornell University Library. 


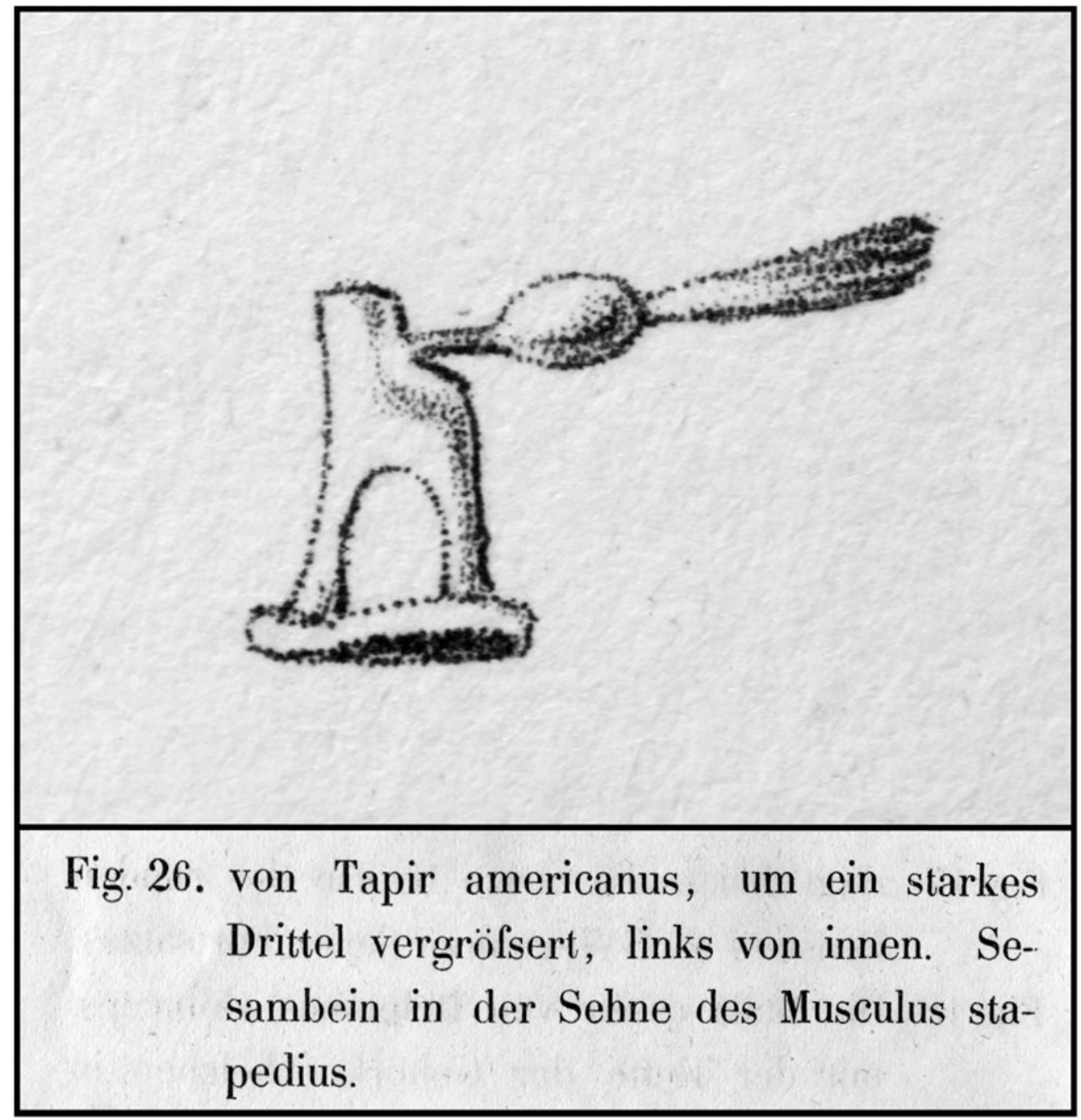

Figure 5.

Joseph Hyrtl's illustration of an ossicle within the stapedial tendon of the American tapir Tapir americanus, reproduced from his 1845 text Vergleichend-anatomische Untersuchungen über das innere Gehörorgan des Menschen und der Säugethiere. 


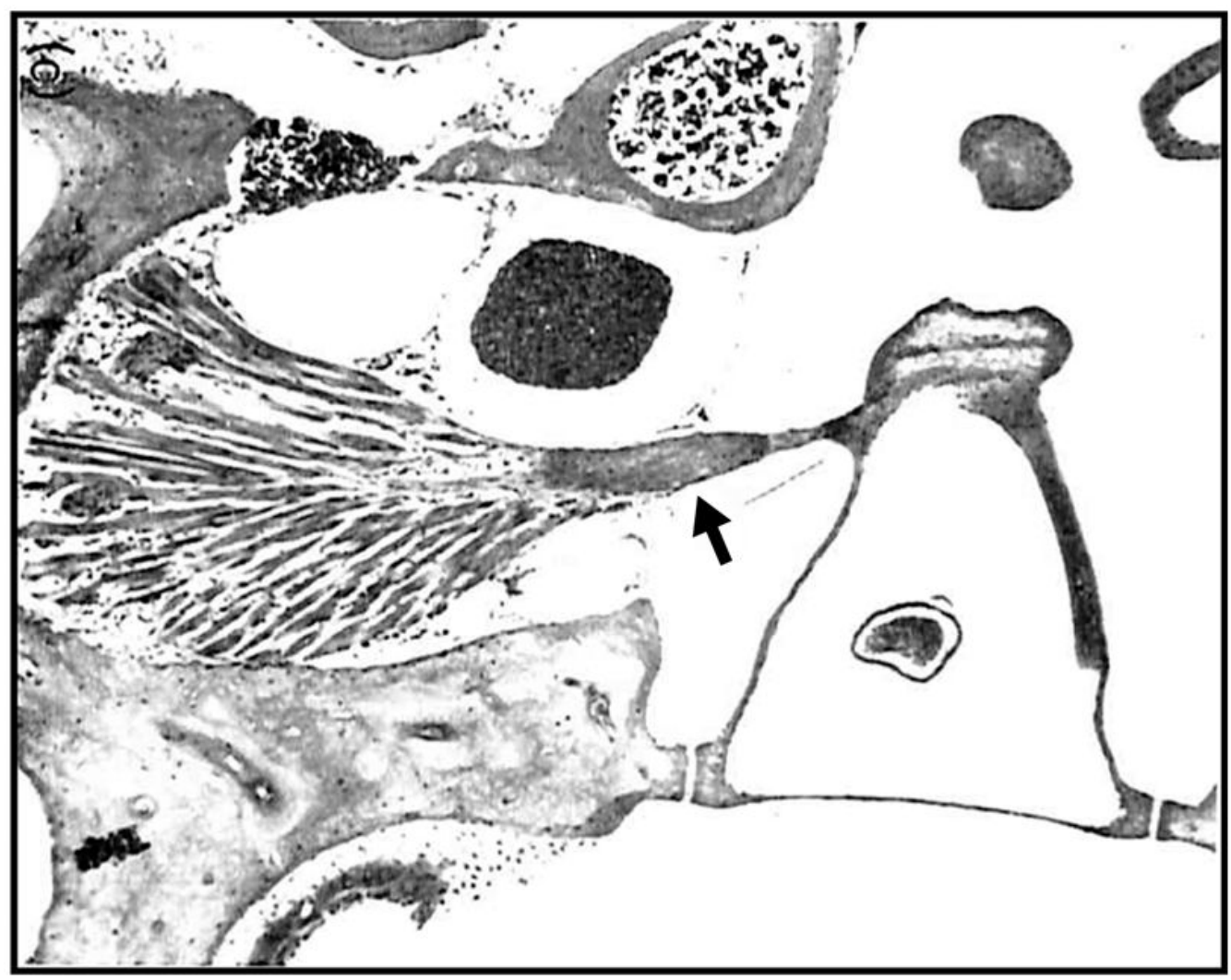

Figure 6.

A reproduction of the plate from Hinchcliffe's 1969 article "Variations in the middle ear of mammalia" depicting Paaw's cartilage (arrow) in the stapes muscle in Seba's short-tailed bat, Carollia perspicillata. Hinchcliffe described the ossicle as an inconstant feature, present in many but not all of the mammals that he examined. Image courtesy of John Wiley and Sons Publishing. 